\title{
The Risk Assessment of Pesticide Ingestion with Fruit and Vegetables for Consumer's Health
}

\author{
Gordana Jurak $\left(\mathbb{D},{ }^{1}\right.$ Jasna Bošnir $\left(\mathbb{D},{ }^{1}\right.$ Domagoj Đikić $\left(\mathbb{D},{ }^{2}\right.$ Ana Mojsović Ćuić $\left(\mathbb{D},{ }^{3}\right.$

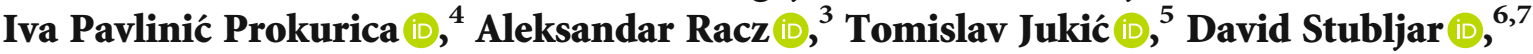 \\ and Andrej Starc $\mathbb{B}^{8}$ \\ ${ }^{1}$ Dr. Andrija Štampar Teaching Institute of Public Health, Zagreb, Croatia \\ ${ }^{2}$ Department of Biology, Faculty of Science, University of Zagreb, Zagreb, Croatia \\ ${ }^{3}$ University of Applied Health Sciences, Zagreb, Croatia \\ ${ }^{4}$ Croatian Agency for Agriculture and Food, Zagreb, Croatia \\ ${ }^{5}$ Department of Internal Medicine, History of Medicine and Medical Ethics, Faculty of Medicine Josip Juraj Strossmayer, \\ Osijek, Croatia \\ ${ }^{6}$ Department of Research \& Development, In-Medico, Metlika, Slovenia \\ ${ }^{7}$ Institute of Microbiology and Immunology Faculty of Medicine Ljubljana, Ljubljana, Slovenia \\ ${ }^{8}$ Faculty of Health Sciences, University of Ljubljana, Ljubljana, Slovenia
}

Correspondence should be addressed to Aleksandar Racz; aleksandar.racz@zvu.hr

Received 24 March 2021; Revised 23 May 2021; Accepted 3 June 2021; Published 15 June 2021

Academic Editor: Hadi Hashemi Gahruie

Copyright (c) 2021 Gordana Jurak et al. This is an open access article distributed under the Creative Commons Attribution License, which permits unrestricted use, distribution, and reproduction in any medium, provided the original work is properly cited.

\begin{abstract}
Pesticides are chemicals used in agriculture to protect crops from pests. In addition to protection during cultivation, they are also used after harvesting to extend the shelf life of products. Postharvest control stands out, especially when it comes to products imported from distant countries, resulting in increased concentration of pesticides and risk to human health consuming such products. In this study, analyses of pesticide residues were performed on 200 samples of fruits and vegetables. Pesticide residues were identified and quantified in 30 out of 200 samples. Study results revealed imazalil to be the most frequently detected pesticide. Risk assessment was performed on the obtained results, and it was carried out separately for adults and for children under 6 years of age. Imazalil showed the highest ARfD percentage for adults (max\% ARfD 251\%), and these values were especially high on risk assessment for children, where they amounted up to max\% ARfD 1087\%. The study of imazalil impact was performed on 16 Swiss albino mice divided into two groups and 4 subgroups. Experimental group animals were treated with the corresponding NOAEL dose of imazalil $(10 \mathrm{mg} / \mathrm{kg})$ for 28 days. Body weight was measured before each pesticide application on a digital electronic Sartorius scale. Peripheral blood analysis was performed after 28-day animal exposure to pesticides. Animals were anesthetized, blood samples were obtained by cardiac puncture, and red blood cell (RBC) count, hemoglobin $(\mathrm{Hb})$ concentration, and white blood cell (WBC) count were determined by standard hematological methods. The organs for determination of imazalil concentration were extracted immediately upon animal sacrifice and stored in a freezer at $-80^{\circ} \mathrm{C}$ until analysis. Results show difference in gain weight, and an increase in WBC count was recorded in the experimental group as compared with a control group of animals. The highest imazalil levels were recorded in adipose tissue (45.2\%o) which proves tendency to accumulate.
\end{abstract}

\section{Introduction}

Croatia belongs to the group of countries with relatively low use of pesticides for soil treatment, which is not the result of the rational pesticide utilization and their strict control, but most likely due to poor agricultural development with very low and nationally inadequate cultivation of agricultural products. Therefore, the Croatian market is overflown with a variety of fruit and vegetables, mostly imported from the European Union countries and other parts of the world. It 
is a well-known and legally justified fact that fruit and vegetables are treated with various types of pesticides to increase gain and food shelf life. Agricultural products can be treated with a single active substance or with several such substances simultaneously, which results in human exposure to their action and the potential adverse health effects. Therefore, it is logical to pose questions related to the combined intake of several active substances and their adverse effects in the human body. There is not enough information either on the combined action of chemicals or of pesticides, including long-standing professional exposure. Available data indicate that $95 \%$ of toxicological studies evaluated exposure to only one chemical [1-3]. A synergistic study of six different pesticides acting upon Daphnia magna as a test organism confirmed the theory on the combinations of some pesticides to exert enhanced toxicological activity [4]. A study conducted on honeybees (Apis mellifera) and bumblebees (Bombus terrestris L) led to similar conclusions [5-7].

Considering residual pesticides in and/or on foodstuff and their safety, a product safe for use in humans is the one that contains particular pesticide in the amount determined by the respective By-law or European Union Directive [8].

The number of active substances as well as the variable solubility and polar characteristics of each individual pesticide has led to the development of various analytical methods for their identification and quantification. Development of multiresidue methods was not simple at all, knowing the very demanding preconditions to be met to enable pesticide quantification in the sample analyzed. Gas chromatography methods using different types of detectors are now available, which can quantify only some of the active pesticide components on the basis of retention times. Besides being quite time-consuming and using large amounts of solvents, these methods produced false-positive results due to interferences from the matrices that coeluted concurrently with the target analyte [9].

In 2003, the Quick, Easy, Cheap, Effective, Rugged, and Safe (QuEChERS) method was introduced and adopted by the analysts as a very rapid, simple, and efficient method [10]. Literature data report high recovery of even $70 \%$ $110 \%$ associated with this method in routine analytical procedures with the use of small amounts of nonpolar diluents $(10 \mathrm{ml})$ [11-13].

This analytical method has provided insight into the qualitative and the quantitative presence of particular pesticides in fresh fruit and vegetables, while confirming the fact that humans are continuously exposed to particular pesticides to some extent if taking fresh fruit and vegetables [14, 15].

In order to determine the possible adverse effect of pesticides on human health by taking fresh fruit and vegetables, the risk should be assessed for each individual pesticide and for their combinations because it is known that two or more substances found together in the body can assume quite different actions than each of them alone [16].

The first attempts at such a risk assessment were reported as early as the 1970s and referred to vinyl chloride, published by the Environmental Protection Agency (EPA), entitled "Quantitative Risk Assessment Community Exposure to Vinyl Chloride" [17]. Over the years, risk assessment has become increasingly important and various tools for risk assessment have been developed and used by researchers [18-23].

In the present study, the multiresidue QuEChERS method was employed for pesticide isolation. A combined technique of gas chromatography and mass spectrometry (GC-MS) was used to determine the presence and level of particular pesticides in selected fresh fruit and vegetables. The potential risk for human health was assessed by the use of the EFSA software PRIMO 3.1 model. The results thus obtained on the prevalence of particular pesticides in the study samples revealed the most prevalent pesticide, which was then tested on experimental animals.

\section{Material and Methods}

A risk assessment of the obtained results was made.

2.1. Preparation of the Fruit and Vegetable Samples by the Use of the QuEChERS Method. A total of 200 samples of fresh fruit and vegetables were analyzed (120 fruit and 80 vegetable samples).

Study samples were divided into three groups according to their characteristics. Both imported and domestic samples were included and analyzed for the presence of pesticides to assess their health safety.

All samples were prepared in the same way, as follows: 1 $\mathrm{kg}$ of sample is homogenized and $10 \mathrm{~g}$ taken for further procedure. Internal TPP standard and $10 \mathrm{ml} \mathrm{ACN,} 4 \mathrm{mg} \mathrm{MgSO}_{4}$, $1 \mathrm{~g} \mathrm{NaCl}, 1 \mathrm{~g}$ trisodium citrate dehydrate, and $0.5 \mathrm{~g}$ disodium hydrogen sesquihydrate are added to the sample. The sample thus prepared is centrifuged for $5 \mathrm{~min}$ at $3500 \mathrm{rpm}[15,24] .6$ $\mathrm{ml}$ of the prepared sample aliquot is taken for further procedure. The previously prepared SPE kit containing $150 \mathrm{mg}$ primary secondary amine (PSA), $150 \mathrm{mg} \mathrm{C18}$, and $900 \mathrm{mg}$ magnesium sulfate is used for the way and fat-containing samples. The SPE kit used for pigmented samples contains $150 \mathrm{mg}$ PSA, $15 \mathrm{mg}$ graphite carbon black (GCB), and 900 mg magnesium sulfate. The SPE kit used for extremely pigmented samples contains $150 \mathrm{mg}$ magnesium sulfate, 44 mg GCB, and magnesium sulfate [15]. The injection volume is $1 \mu \mathrm{l}$.

2.2. Pesticide Identification and Quantification by the GC-MS Technique. The mass proportion of residual pesticides was determined on a GCMS-QP 2010 Plus equipped with PTV autoinjector model AOC-20i. The Restek capillary column RTX-OPPPesticides ( $30 \mathrm{~m} \times 0.25 \mathrm{~mm}$ i.d.) and film thickness 0.25 , with helium (He 6.0) flow of $1.99 \mathrm{ml} / \mathrm{min}$, were employed for separation.

Pesticide identification and quantification were performed by the use of the SIM mode analysis based on one main ion and two confirmation ions and retention time. The concentration is calculated automatically by the use of the GCMS solution software, based on the ratio of the analyte peak surface divided by the standard peak surface.

Recovery: recovery of $70 \%-120 \%$ proposed in the "Analytical Quality Control and Method Validation Procedures for Pesticide Residues Analysis in Food and Feed" was 
achieved by the use of three inoculated representative samples (Table 1) [25].

Limit of quantification: quantification limit was defined as the lowest inoculated level meeting the method performance to the acceptable criterion (mean recovery for each representative sample ranging from $70 \%$ to $120 \%$ with RSD < 20\%) [25].

2.3. Risk Assessment. Risk assessment for acute exposure to pesticides was calculated by the EFSA Pesticide Residue Intake Model-PRIMo model (rev 3.1), using the concentration values presented in the appropriate table and acute reference dose (ARfD) if it was established. Pf (peeling factors) values for citrus fruits and potato are not used in these calculations. Risk assessment was performed separately for adults and for children under 6 years of age. Food is considered safe for consumption if the estimated intake of harmful substances does not exceed the ADI or ARfD (acute reference dose) values. During exposure assessment, except for data on concentrations of residue, consumption data for a particular type of food has also been taken into account, bearing in mind the nutritional habits of a particular population.

2.4. Experimental Animals. The study was performed on 16 male and female Swiss albino mice. The animals were obtained from the Department of Animal Physiology, Faculty of Science University of Zagreb, Croatia. The study protocol was approved by the above institution's Ethics Committee. Experiments were carried out in line with the respective guidelines on keeping and using experimental animals [26] and European Union Directive [27].

Animals were fed a standard laboratory diet, tap water ad libitum, and received 12 hours of light per day. The standardized diet was 4 RF 21, Mucedola (Settimo Milanese, Italy). The composition of standardized pellet mouse feed included wheat, wheat straw, hazelnut skins, maize, soybean hulled, corn gluten feed, fishmeal, dicalcium phosphate, sodium chloride, whey powder, soybean oil, yeast, contained $12 \%$ moisture, $18.5 \%$ protein, $3 \%$ fats, $6 \%$ crude fibers, $7 \%$ crude ash, E672 (vitamin A), E671 (vitamin E), E1 (Fe), E2 (I), E3 $(\mathrm{Co}), \mathrm{E} 4(\mathrm{Cu}), \mathrm{E} 5(\mathrm{Mn})$, and E6 ( $\mathrm{Zn})$. Experimental and control animals were kept under identical conditions.

At initial pesticide application, animals were aged $60 \pm 5$ days, mean weight $25 \mathrm{~g}$.

Animals $(n=16)$ were divided into control and experimental groups. Each group consisted of 8 mice of both sexes (4 males and 4 females). During 28 days, the control group received pure edible sunflower oil $(0.25 \mathrm{ml} / 25 \mathrm{~g}$ body weight per day) by gavage. The experimental group was treated with the corresponding NOAEL dose of imazalil $(10 \mathrm{mg} / \mathrm{kg})$ for 28 days $[17,27]$. The concentrated pesticide (Sigma, proanalysis, $99.5 \%$ purity), was suspended in pure edible sunflower oil before application. The pesticide was administered orally by gavage in the same volume as in the control animals $(0.25 \mathrm{ml} / 25 \mathrm{~g}$ body weight per day). All animals in both groups were sacrificed on day 28 of pesticide treatment.

Body weight was measured before each pesticide application on a digital electronic Sartorius scale, with precision of $\pm 0.1 \mathrm{~g}$. Peripheral blood analysis was performed after 28-day animal exposure to pesticides. Animals were anesthetized (Xylapan/Narcetan), blood samples were obtained by cardiac puncture, and red blood cell (RBC) count, hemoglobin $(\mathrm{Hb})$ concentration, and white blood cell (WBC) count were determined by the Beckman Coulter hematological counter. The organs for determination of imazalil concentration were extracted immediately upon animal sacrifice and stored in a freezer at $-80^{\circ} \mathrm{C}$ until analysis.

Organ weight was measured on a torsion balance (Torsion Balance, USA) with precision of $\pm 0.1 \mathrm{mg}$. Muscle, kidney, adipose tissue, and brain samples from 4 male and 4 female mice were taken for residue pesticide analysis. The organs were pooled (in order to gain enough sample for pesticide extraction since mouse organs in mg weight ratio) and prepared by the QuEChERS method for analysis of imazalil residues by the GC-MS technique and analyzed as triplicate. Upon determination of imazalil concentration in particular organs, the mean concentrations were calculated and expressed as imazalil \%o of entry dose in the analyzed organs from male and female animals.

\section{Results}

3.1. Determination of Residual Pesticide Concentration in Study Samples. Pesticide residues were detected in 31 of 200 $(15.5 \%)$ fresh fruit and vegetable samples analyzed. In fruit samples, pesticide residues were found in 22 of 120 (18.3\%) samples. Imazalil was detected in 18 samples at a concentration range of $0.020-4.1 \mathrm{mg} / \mathrm{kg}$. Chlorpyriphos was found in 8 samples at a concentration ranging from $0.030 \mathrm{mg} / \mathrm{kg}$ to 0.27 $\mathrm{mg} / \mathrm{kg}$ and phorate in 3 samples at low concentration of $0.011 \mathrm{mg} / \mathrm{kg}$ to $0.019 \mathrm{mg} / \mathrm{kg}$. In one sample, ethion is detected at concentration $0.27 \mathrm{mg} / \mathrm{kg}$. Imazalil accounted for the highest proportion $(66.6 \%)$ of pesticides detected in fruits. In 8 fruit samples, pesticide residues exceeded the maximal allowable concentration (MAC) and were labeled as unsafe for human use. Results are shown in Table 2.

3.2. Risk Assessment. The risk was assessed separately for each pesticide detected positive. Risk assessment was calculated according to the EFSA for acute and chronic exposure to pesticides for which the acute reference dose (ARfD) has been established. Risk assessment was performed separately for adults and for children under 6 years of age. The results are shown in Table 2.

Imazalil was the most frequently detected pesticide in our study. Imazalil showed the highest ARfD percentage of adults (max\% ARfD $251 \%$ ), and these values were especially high in risk assessment for children, where they amounted up to max\% ARfD 1087\%. Risk assessment for adults detected that imazalil values exceeded MAC in $8(44.4 \%)$ out of 18 samples where imazalil was found, while for children, they exceeded MAC in $72.2 \%$ (13 of 18 ) samples.

3.3. Results of Animal Testing. As shown in Table 3 at the end of the experimental period, body weight of treated animals did not differ significantly from that in the control group. Unlike body weight, weight gain showed a statistically significant difference $(p \leq 0.05)$ between the experimental and control groups of animals. 
TABLE 1: Validation results: mean recovery and relative standard deviation from three representative samples (apple, cucumber, and lemon) inoculated with $0.1 \mu \mathrm{g} / \mathrm{ml}$ to $0.25 \mu \mathrm{g} / \mathrm{ml}$.

\begin{tabular}{|c|c|c|c|c|c|c|}
\hline \multirow{2}{*}{ Pesticide } & \multicolumn{2}{|c|}{ Apple $(n=5)^{*}$} & \multicolumn{2}{|c|}{ Cucumber $(n=5)^{*}$} & \multicolumn{2}{|c|}{ Lemon $(n=5)^{*}$} \\
\hline & Recovery (\%) & RSD (\%) & Recovery (\%) & RSD (\%) & Recovery (\%) & RSD (\%) \\
\hline Aldrin & 98 & 3.6 & 97 & 1.5 & 104 & 1.2 \\
\hline Bromophos ethyl & 91 & 6.8 & 108 & 5.6 & 102 & 5.9 \\
\hline Chlorfenvinphos & 77 & 5.8 & 88 & 4.8 & 103 & 4.9 \\
\hline Chlorpyriphos & 87 & 1.8 & 109 & 1.6 & 99 & 1.3 \\
\hline Chlorpyriphos-methyl & 102 & 7.8 & 93 & 7.9 & 105 & 7.4 \\
\hline DDD & 88 & 4.8 & 77 & 4.6 & 103 & 4.5 \\
\hline DDE & 106 & 4.9 & 95 & 5.8 & 99 & 4.4 \\
\hline DDT & 100 & 12.3 & 88 & 13.8 & 104 & 12.8 \\
\hline Diazinon & 94 & 7.8 & 94 & 8.7 & 100 & 8.8 \\
\hline Dieldrin & 104 & 5.6 & 86 & 7.4 & 102 & 7.5 \\
\hline Dichlorvos & 97 & 2.9 & 90 & 2.7 & 96 & 2.9 \\
\hline Dimethoate & 78 & 10.1 & 92 & 5.9 & 102 & 4.3 \\
\hline Disulfoton & 103 & 11.7 & 91 & 10.4 & 104 & 8.1 \\
\hline Endosulfan-I & 90 & 3.9 & 89 & 5.2 & 102 & 3.8 \\
\hline Endosulfan-II & 88 & 2.4 & 96 & 3.6 & 99 & 1.2 \\
\hline Endosulfan-sulfate & 91 & 4.6 & 89 & 2.5 & 102 & 3.7 \\
\hline Endrin & 104 & 8.5 & 86 & 8.6 & 106 & 6.2 \\
\hline Ethion & 99 & 7.1 & 89 & 6.2 & 87 & 6.0 \\
\hline HCH-alpha & 104 & 1.9 & 93 & 2.8 & 109 & 2.8 \\
\hline $\mathrm{HCH}$-beta & 102 & 14.2 & 102 & 13.6 & 99 & 16.5 \\
\hline HCH-gamma & 99 & 10.9 & 89 & 10.3 & 86 & 11.4 \\
\hline Heptachlor & 99 & 5.4 & 91 & 5.2 & 104 & 5.7 \\
\hline Fensulfothion & 99 & 12.3 & 84 & 16.4 & 82 & 17.8 \\
\hline Heptachlor-epoxide & 99 & 8.4 & 96 & 4.3 & 109 & 4.5 \\
\hline Fosfamidon & 101 & 4.6 & 102 & 4.8 & 100 & 5.4 \\
\hline Imazalil & 98 & 8.1 & 98 & 8.4 & 109 & 6.5 \\
\hline Fenchlorphos & 106 & 7.3 & 91 & 7.6 & 109 & 6.9 \\
\hline Fenthion & 105 & 7.7 & 94 & 7.3 & 90 & 8.9 \\
\hline Malathion & 92 & 2.8 & 72 & 2.9 & 100 & 3.3 \\
\hline Methacrifos & 85 & 4.6 & 79 & 4.3 & 100 & 1.6 \\
\hline Methamidophos & 105 & 16.8 & 94 & 12.6 & 92 & 19.6 \\
\hline Mevinphos & 107 & 4.2 & 91 & 7.5 & 110 & 6.5 \\
\hline Parathion-ethyl & 97 & 2.1 & 106 & 2.3 & 101 & 3.5 \\
\hline Parathion-methyl & 74 & 11.2 & 76 & 11.4 & 83 & 11.8 \\
\hline Pirimiphos & 100 & 10.7 & 99 & 10.8 & 106 & 12.8 \\
\hline Phenitrotion & 84 & 4.8 & 106 & 4.3 & 105 & 4.1 \\
\hline Phorate & 106 & 5.6 & 96 & 3.9 & 98 & 3.5 \\
\hline Quinalphos & 106 & 8.0 & 90 & 7.8 & 102 & 7.0 \\
\hline
\end{tabular}

${ }^{*}$ Each representative sample was prepared and analyzed five times.

There was no statistically significant difference in RBC count and hemoglobin concentration between the imazalil exposed group and the control group $(p \leq 0.05)$. However, a statistically significant $(p \leq 0.05)$ increase in WBC count was recorded in the experimental group as compared with a control group of animals (Table 4).

The mean imazalil concentrations in the muscle, kidney, adipose tissue, and brain of male and female experimental animals, expressed in \%o, are shown in Figure 1. The highest ima- zalil levels were recorded in adipose tissue $(45.2 \% 0)$, followed by the kidney $(30.6 \%)$, muscle $(10.6 \%)$, and brain $(9.2 \% 0)$.

\section{Discussion}

In order to achieve better yields or to extend their shelf life, fruits and vegetables are treated with pesticides. Given that Croatia is a relatively small country with low agricultural production, it is forced to import fruits and vegetables from 
TABLE 2: Pesticide residue concentration and assessment of acute exposure of adults and children to detected pesticides.

\begin{tabular}{|c|c|c|c|c|c|c|}
\hline Pesticide & Matrix & $\begin{array}{c}\text { Concentration } \\
(\mathrm{mg} / \mathrm{kg})\end{array}$ & $\begin{array}{c}\% \text { of acute } \\
\text { ARfD adults }\end{array}$ & $\begin{array}{c}\text { IESTI } \\
(\mu \mathrm{g} / \mathrm{kg} \text { bw/day })\end{array}$ & $\begin{array}{c}\% \text { of acute } \\
\text { ARfD children }\end{array}$ & $\begin{array}{c}\text { IESTI } \\
(\mu \mathrm{g} / \mathrm{kg} \text { bw/day })\end{array}$ \\
\hline Imazalil & Orange & 4.10 & 251 & 126 & 1087 & 544 \\
\hline Imazalil & Orange & 3.50 & 215 & 107 & 928 & 464 \\
\hline Imazalil & Orange & 3.30 & 202 & 101 & 875 & 438 \\
\hline Imazalil & Orange & 3.33 & 204 & 102 & 883 & 442 \\
\hline Imazalil & Orange & 2.90 & 178 & 89 & 769 & 385 \\
\hline Imazalil & Orange & 2.55 & 156 & 78 & 676 & 338 \\
\hline Imazalil & Orange & 2.55 & 156 & 78 & 676 & 338 \\
\hline Imazalil & Orange & 0.90 & 55 & 28 & 239 & 119 \\
\hline Imazalil & Orange & 0.72 & 44 & 22 & 191 & 95 \\
\hline Imazalil & Orange & 0.096 & 6 & 2,9 & 25 & 13 \\
\hline Imazalil & Clementine orange & 2.40 & 86 & 43 & 285 & 142 \\
\hline Imazalil & Pomelo fruit & 0.02 & 0,7 & 0,36 & 2 & 1,2 \\
\hline Imazalil & Mandarin orange & 2.40 & 86 & 43 & 285 & 142 \\
\hline Imazalil & Mandora fruit & 3.80 & 136 & 68 & 451 & 225 \\
\hline Imazalil & Lemon & 1.53 & 27 & 14 & 105 & 52 \\
\hline Imazalil & Lemon & 0.33 & 6 & 3 & 23 & 11 \\
\hline Imazalil & Grapefruit & 0.37 & 13 & 6,6 & 58 & 29 \\
\hline Imazalil & Grapefruit & 0.14 & 5 & 2,6 & 23 & 11 \\
\hline Ethion & Orange & 0.27 & 41 & 0,83 & 179 & 3,6 \\
\hline Chlorpyriphos & Orange & 0.22 & 135 & 6,7 & 584 & 28 \\
\hline Chlorpyriphos & Grapefruit & 0.21 & 75 & 3,8 & 330 & 16 \\
\hline Chlorpyriphos & Grapefruit & 0.09 & 32 & 1,6 & 141 & 7,1 \\
\hline Chlorpyriphos & Lemon & 0.08 & 14 & 0,72 & 55 & 2,7 \\
\hline Chlorpyriphos & Grapefruit & 0.11 & 39 & 2,0 & 173 & 8,6 \\
\hline Chlorpyriphos & Pear & 0.03 & 18 & 0,92 & 83 & 4,2 \\
\hline Chlorpyriphos & Peach & 0.27 & 101 & 5,1 & 513 & 26 \\
\hline Chlorpyriphos & Grapes & 0.07 & 47 & 2,4 & 102 & 5,1 \\
\hline Phorate & Potato & 0.014 & 14 & 0,42 & 72 & 2,2 \\
\hline Phorate & Tomato & 0.019 & 10 & 0,30 & 37 & 1,1 \\
\hline Phorate & Tomato & 0.011 & 6 & 0,17 & 21 & 0,64 \\
\hline
\end{tabular}

IESTI = international estimated short-term intake; bw = body weight; $\mathrm{ARfD}=$ acute reference dose.

TABLE 3: Body weight and weight gain in Swiss albino mice after 28 days of treatment with imazalil expressed as mean standard deviation (SD) and median.

\begin{tabular}{lccc}
\hline Group* & & $\begin{array}{c}\text { Initial body weight at the } \\
\text { beginning of experiment }\end{array}$ & $\begin{array}{c}\text { Weight gain after 28 days } \\
\text { of experiment }\end{array}$ \\
\hline Control & Mean \pm standard deviation (SD) & $25.8 \pm 3.3$ & $+2.0 \pm 0.8$ \\
& Median & 25.2 & +2.2 \\
\hline \multirow{2}{*}{ Imazalil } & Mean \pm standard deviation (SD) & $25.0 \pm 3.1$ & $+0.3 \pm 1.3^{\mathrm{a}}$ \\
& Median & 25.5 & +0.2 \\
\hline
\end{tabular}

${ }^{*} 8$ Swiss albino mice per group (4 males and 4 females). ${ }^{a}$ Means with superscript (letter) are significantly different from control ( $\left.p \leq 0.05\right)$.

countries outside the EU. When fruits and vegetables are imported to EU member states, it is necessary to analyze pesticide residues. Fruit samples are homogenized with the peel, which often contains pesticide residues [28]. The results of the analysis show whether the sample complies with Regulation 396/2005 and whether it is safe or harmful to human health [29]. Samples that do not comply with the regulation are sent to risk assessment.

A total of 200 fruits and vegetable samples were analyzed using a gas chromatograph with mass spectrometry. The results obtained by the analysis were evaluated. The assessment of chronic and acute dietary exposure to pesticide 
TABLE 4: Number of erythrocytes (RBC), white blood cells (WBC), and hemoglobin concentration in Swiss albino mice after 28 days of treatment with imazalil expressed as mean standard deviation (SD), median, minimum, and maximum.

\begin{tabular}{|c|c|c|c|c|c|}
\hline & Mean \pm standard deviation (SD) & Median & Minimum & Maximum & Mean \pm standard deviation (SD) (males + females) \\
\hline Group* & & $3 \mathrm{C}$ & & & \\
\hline \multicolumn{6}{|l|}{ Control } \\
\hline Males (M) & $7.98 \pm 0.35$ & 8.04 & 7.40 & 8.28 & \multirow{2}{*}{$8.00 \pm 1.12$} \\
\hline Females (F) & $8.01 \pm 1.55$ & 8.12 & 5.44 & 10.12 & \\
\hline \multicolumn{6}{|l|}{ Imazalil } \\
\hline Males (M) & $8.72 \pm 0.79$ & 8.40 & 7.80 & 9.80 & \multirow{2}{*}{$8.89 \pm 0.80$} \\
\hline Females (F) & $9.09 \pm 0.84$ & 8.90 & 7.84 & 10.24 & \\
\hline Group & \multicolumn{4}{|c|}{ Hemoglobin concentration } & \\
\hline Control & & & & & \\
\hline Males (M) & $108.24 \pm 6.55$ & 108.40 & 100.40 & 116.00 & \multirow{2}{*}{$119.24 \pm 16.41$} \\
\hline Females (F) & $128.40 \pm 16.81$ & 126.60 & 110.80 & 150.40 & \\
\hline \multicolumn{6}{|l|}{ Imazalil } \\
\hline Males (M) & $123.60 \pm 13.77$ & 124.40 & 100.40 & 142.80 & \multirow{2}{*}{$128.74 \pm 13.87$} \\
\hline Females (F) & $134.73 \pm 12.41$ & 135.20 & 113.60 & 150.40 & \\
\hline Group & & $\mathrm{BC}$ & & & \\
\hline \multicolumn{6}{|l|}{ Control } \\
\hline Males (M) & $3.28 \pm 0.37$ & 3.20 & 2.94 & 3.79 & \multirow{2}{*}{$3.24 \pm 1.09$} \\
\hline Females (F) & $4.12 \pm 1.73$ & 4.52 & 0.92 & 6.00 & \\
\hline \multicolumn{6}{|l|}{ Imazalil } \\
\hline Males (M) & $3.69 \pm 0.96^{\mathrm{a}}$ & 3.60 & 2.22 & 4.88 & \multirow{2}{*}{$4.16 \pm 1.16^{\mathrm{a}}$} \\
\hline Females (F) & $4.56 \pm 1.07^{\mathrm{a}}$ & 4.84 & 2.91 & 6.00 & \\
\hline
\end{tabular}

${ }^{*} 8$ Swiss albino mice per group ( 4 males and 4 females). ${ }^{a}$ Means with superscript (letter) are significantly different from control ( $\left.p \leq 0.05\right)$.

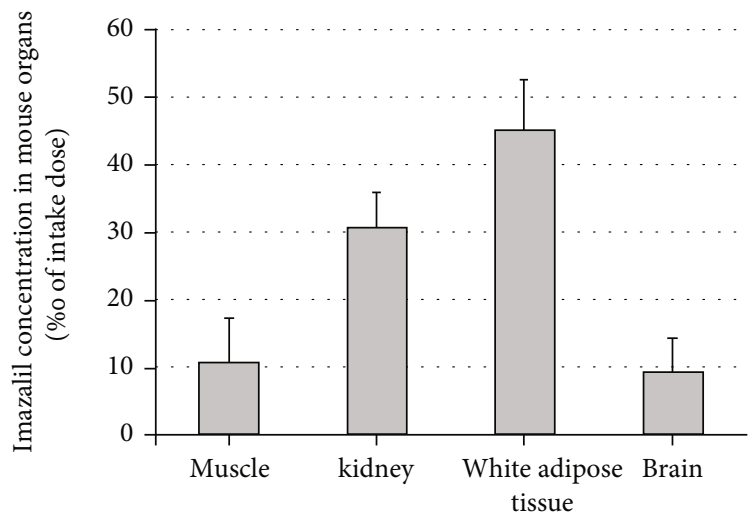

FIgURE 1: Imazalil accumulated in analyzed organs of Swiss albino mice (pooled samples of 8 mice, 4 male +4 females). The columns represent mean values (\%o) of imazalil in the muscle, kidney, white adipose tissue, and brain of Swiss albino mice after 28-day imazalil exposure. The wishers represent the standard deviation of the mean of triplicate analysis of a pooled sample.

residues is estimated by using a calculation model developed by EFSA (PRIMo-Pesticide Residues Intake Model) [30]. The most detected pesticides and pesticide with the highest ARfD percentage were imazalil. Further research was performed on laboratory mice fed with sunflower oil with added Imazalil at NOEL doses [31].
This research was conducted on fruits and vegetables that arrived at the laboratory for pesticide residue analysis. Samples were submitted by inspectors during product inspections in stores or inspection during import. The largest number of samples consisted of imported samples from countries outside EU. From 200 samples analyzed, pesticide residues were detected in 30 samples. In fruit samples, pesticide residues were found in 27 of $120(22.5 \%)$ samples. Imazalil was detected in 18 samples at a concentration range of $0.020-4.1 \mathrm{mg} / \mathrm{kg}$. Imazalil is a fungicide that is mainly used as a postharvest pesticide so that means that it should be located on the peel of oranges [32]. A study conducted by Swiss researchers on citrus fruits proved that imazalil was detected in $70 \%$ of cases [33]. Chlorpyriphos was found in 8 samples at a concentration ranging from $0.030 \mathrm{mg} / \mathrm{kg}$ to $0.27 \mathrm{mg} / \mathrm{kg}$. Chlorpyriphos is an organophosphorus insecticide which is widely used in agriculture. Due to the risk to human health that this pesticide presents and also pollutes the environment, it is banned in the EU [34].

Phorate was detected in 3 samples at very low concentration from $0.011 \mathrm{mg} / \mathrm{kg}$ to $0.019 \mathrm{mg} / \mathrm{kg}$. Phorate is organophosphate used as insecticide, and it is banned in EU. Although it is EU forbidden in third countries, it can still be found. The presence of phorate was shown in a study by Indian researchers [35]. In one sample, ethion is detected at concentration of $0.27 \mathrm{mg} / \mathrm{kg}$.

The results of the analysis were processed and sent for risk assessment in the Croatian Agency for Agriculture and 
Food. The risk was assessed separately for each pesticide detected positive. Risk assessment was calculated acute and chronic exposure to pesticides for which the acute reference dose (ARfD) has been established. Risk assessment was performed separately for adults and for children under 6 years of age, and the results are shown in Table 3. The highest ARfD for the adult and children was calculated for pesticide imazalil in orange with quantified concentration of $4.1 \mathrm{mg} / \mathrm{kg}$.

After imazalil proved to be the most common pesticide in the analyzed samples, a study was conducted on the laboratory mice. The pesticide was administered orally via cannula, suspended in pure edible sunflower oil before application. Control group animals received pure edible sunflower oil, $0.2 \mathrm{ml}$ per day. Testing included measurement of body weight and weight gain, peripheral blood analysis, and determination of imazalil concentration in the muscle, kidney, adipose tissue, and brain of treated animals. Results show difference in gain weight, and an increase in WBC count was recorded in the experimental group as compared with a control group of animals (Table 4). The highest imazalil levels were recorded in adipose tissue $(45.2 \%$ ) which proves tendency to accumulate.

\section{Conclusion}

Pesticide residues were detected in 30 of 200 (15.0\%) fresh fruit and vegetable samples analyzed. In fruit samples, pesticide residues were found in 27 of 120 (22.5\%) samples.

In 9 fruit samples, pesticide residues exceeded the maximal allowable concentration (MAC) and were labeled as unsafe for human use. Study results revealed imazalil to be the most frequently detected pesticide.

Assessment of exposure to all pesticides detected that imazalil yielded the highest percentage of ARfD value, which was most pronounced in children, even up to $1087 \%$ ARfD.

In animal experiments, imazalil exerted a high inflammatory potential and caused leukocytosis. Upon administration of NOAEL dose of imazalil for 28 days as well as after the pesticide biotransformation in the mouse body, imazalil residues were verified in all the four organs analyzed. In addition, imazalil showed the highest potential of bioaccumulation in the adipose tissue of both male and female animals, while the lowest pesticide concentrations were recorded in the brain tissue.

These results indicate bioaccumulation of the pesticide in body organs, even with the use of low pesticide doses over a longer period and following its biotransformation in the body, whereby each particular organ exhibits a variable bioaccumulation potential.

Study results indicate that imazalil poses a major risk not only due to its high prevalence but also for the high risk to human health in countries like Croatia, where great amounts of citrus fruits are consumed and citrus rind is an important dietary component.

\section{Data Availability}

The underlying data supporting the results of the study can be found at the University of Osijek through hyperlink: http://zpio.unios.hr/wp-content/uploads/radovi/dokt.disert/ gordana.jurak.pdf.

\section{Conflicts of Interest}

The authors declare that there is no conflict of interest regarding the publication of this paper. The authors whose names are listed immediately below certify that they have no affiliations with or involvement in any organization or entity with any financial interest (such as honoraria; educational grants; participation in speakers' bureaus; membership, employment, consultancies, stock ownership, or other equity interest; and expert testimony or patent-licensing arrangements) or nonfinancial interest (such as personal or professional relationships, affiliations, knowledge, or beliefs) in the subject matter or materials discussed in this manuscript.

\section{References}

[1] Scientific Committee on Health and Environmental Risks SCHER, Toxicity and Assessment of Chemical Mixtures, European Union, Scientific Committees, Brussels, EU, 2012, https:// ec.europa.eu/health/scientific_committees/environmental_ risks/docs/scher_o_155.pdf.

[2] F. Plavšić, Temeljni pojmovi iz toksikologije za osobe koje rades otrovima, Korunić d.o.o, Zagreb, 1999.

[3] S. K. Bopp, R. Barouki, W. Brack et al., "Current EU research activities on combined exposure to multiple chemicals," Environment International, vol. 120, pp. 544-562, 2018.

[4] K. B. Nørgaard and N. Cedergreen, "Pesticide cocktails can interact synergistically on aquatic crustaceans," Environmental Science and Pollution Research, vol. 17, no. 4, pp. 957-967, 2010.

[5] G. Glavan and J. Bozic, "The synergy of xenobiotics in honey bee Apis mellifera: mechanisms and effects," Acta Biologica Slovenica, vol. 56, no. 1, pp. 11-25, 2013.

[6] F. Sgolastra, P. Medrzycki, L. Bortolotti et al., "Synergistic mortality between a neonicotinoid insecticide and an ergosterol-biosynthesis-inhibiting fungicide in three bee species," Pest Management Science, vol. 73, no. 6, pp. 12361243, 2017.

[7] R. Raimets, R. Karise, M. Mänd et al., "Synergistic interactions between a variety of insecticides and an ergosterol biosynthesis inhibitor fungicide in dietary exposures of bumble bees (Bombus terrestris L.)," Pest Management Science, vol. 74, no. 3, pp. 541-546, 2018.

[8] "Regulation (EC) No 396/2005 of the European Parliament and of the Council of 23 February 2005 on maximum residue levels of pesticides in or on food and feed of plant and animal origin and amending Council Directive 91/414/EEC, pp. 1-16, Official Journal of the European Union OJ L 70, 16.3.2005, https://eur-lex.europa.eu/eli/reg/2005/396/oj.

[9] A. Beyer and M. Biziuk, "Methods for determining pesticides and polychlorinated biphenyls in food samples-problems and challenges," Critical Reviews in Food Science and Nutrition, vol. 48, no. 10, pp. 888-904, 2008.

[10] M. Anastassiades, S. J. Lehotay, D. Štajnbaher, and F. J. Schenck, "Fast and easy multiresidue method employing acetonitrile extraction/partitioning and "dispersive solid-phase extraction" for the determination of pesticide residues in produce," Journal of AOAC International, vol. 86, no. 2, pp. 412-431, 2003.

[11] S. J. Lehotay, A. D. Kok, M. Hiemstra, and P. V. Bodegraven, "Validation of a fast and easy method for the determination 
of residues from 229 pesticides in fruits and vegetables using gas and liquid chromatography and mass spectrometric detection," Journal of AOAC International, vol. 88, no. 2, pp. 595-614, 2005.

[12] M. C. Bruzzoniti, L. Checchini, R. M. De Carlo, S. Orlandini, L. Rivoira, and M. Del Bubba, "QuEChERS sample preparation for the determination of pesticides and other organic residues in environmental matrices: a critical review," Analytical and bioanalytical chemistry, vol. 406, no. 17, pp. 4089-4116, 2014.

[13] E. Boes, R. T. Rosmalina, Y. S. Ridwan, W. C. Nugraha, and R. Yusiasih, "Development of validated method using QuEChERS technique for organochlorine pesticide residues in vegetable," Procedia Chemistry, vol. 16, pp. 229-236, 2015.

[14] F. J. Schenck and J. E. Hobbs, "Evaluation of the quick, easy, cheap, effective, rugged, and safe (QuEChERS) approach to pesticide residue analysis," Bulletin of Environmental Contamination and Toxicology, vol. 73, no. 1, pp. 24-30, 2004.

[15] S. J. Lehotay, K. A. Son, H. Kwon et al., "Comparison of QuEChERS sample preparation methods for the analysis of pesticide residues in fruits and vegetables," Journal of Chromatography A, vol. 1217, no. 16, pp. 2548-2560, 2010.

[16] N. Singh, V. K. Gupta, A. Kumar, and B. Sharma, "Synergistic effects of heavy metals and pesticides in living systems," Frontiers in Chemistry, vol. 5, p. 70, 2017.

[17] A. M. Kuzmack and R. E. McGaughy, "Quantitative risk assessment for community exposure to vinyl chloride," in US Environmental Protection Agency, Document display |NEPIS| US EPA, 1975.

[18] C. L. Stephenson and C. A. Harris, "An assessment of dietary exposure to glyphosate using refined deterministic and probabilistic methods," Food and Chemical Toxicology, vol. 95, pp. 28-41, 2016.

[19] C. Sieke, B. Michalski, and T. Kuhl, "Probabilistic dietary risk assessment of pesticide residues in foods for the German population based on food monitoring data from 2009 to 2014," Journal of Exposure Science \& Environmental Epidemiology, vol. 28, no. 1, pp. 46-54, 2018.

[20] M. Minuț, M. Roșca, R. M. Hlihor, P. Cozma, and M. Gavrilescu, "Modelling of health risk associated with the intake of pesticides from Romanian fruits and vegetables," Sustainability, vol. 12, no. 23, p. 10035, 2020.

[21] C. M. Benbrook and D. R. Davis, "The dietary risk index system: a tool to track pesticide dietary risks," Environmental Health, vol. 19, no. 1, pp. 103-118, 2020.

[22] D. Kumari and S. John, "Health risk assessment of pesticide residues in fruits and vegetables from farms and markets of Western Indian Himalayan region," Chemosphere, vol. 224, pp. 162-167, 2019.

[23] C. M. Benbrook, D. L. Sexson, J. A. Wyman et al., "Developing a pesticide risk assessment tool to monitor progress in reducing reliance on high-risk pesticides," American Journal of Potato Research, vol. 79, no. 3, pp. 183-199, 2002.

[24] T. D. Nguyen, J. E. Yu, D. M. Lee, and G. H. Lee, “A multiresidue method for the determination of 107 pesticides in cabbage and radish using QuEChERS sample preparation method and gas chromatography mass spectrometry," Food Chemistry, vol. 110, no. 1, pp. 207-213, 2008.

[25] European Commission Directorate General For Health And Food Safety, SANTE/2017/11813, Analytical quality control and method validation procedures for pesticide residues analy- sis in food and feed, 2017, https://ec.europa.eu/food/sites/food/ files/plant/docs/pesticides_mrl_guidelines_wrkdoc_201711813.pdf.

[26] Republic of Croatia, Ministry of Agriculture, Pravilnik o zaštiti životinja koje se koriste $u$ znanstvene svrhe / Rules on the protection of animals used for scientific purposes, vol. 55, Narodne novine / Offical Gazzette Republic of Croatia, 2013, https:// narodne-novine.nn.hr/clanci/sluzbeni/2013_05_55_1129 .html.

[27] The European Parliament and the Council of the European Union, Directive 2010/63/EU of the European Parliament and of the Council of 22 September 2010 on the protection of animals used for scientific purposes, Official Journal of the European Union OJ L 276/33, 20.10.2010, https://eur-lex.europa.eu/LexUriServ/ LexUriServ.do?uri=OJ:L:2010:276:0033:0079:en:PDF.

[28] Y. Li, B. Jiao, Q. Zhao et al., "Effect of commercial processing on pesticide residues in orange products," European Food Research and Technology, vol. 234, no. 3, pp. 449-456, 2012.

[29] European Food Safety Authority (EFSA), A. Brancato, D. Brocca et al., "Review of the existing maximum residue levels for chlorpyrifos according to Article 12 of Regulation (EC) No 396/2005," EFSA Journal, vol. 15, no. 3, article e04733, 2017.

[30] European Food Safety Authority (EFSA), A. Brancato, D. Brocca et al., "Use of EFSA pesticide residue intake model (EFSA PRIMo revision 3)," EFSA Journal, vol. 16, no. 1, article e05147, 2018

[31] E. D. Caldas, "Introduction to dietary risk assessment of pesticides," in Food Safety Assessment of Pesticides Residues, pp. 1-12, World scientific publish. Europe Ltd, London, 2017, https://www.researchgate.net/profile/Eloisa-Caldas/publication/ 312163982_Introduction_to_Dietary_Risk_Assessment_of_ Pesticides/links/59e76e2e0f7e9bed362bf238/Introduction-toDietary-Risk-Assessment-of-Pesticides.pdf.

[32] A. Kruve, A. Lamos, J. Kirillova, and K. Herods, "Pesticide residues in commercially available oranges and evaluation of potential washing methods," Proceedings of the Estonian Academy of Sciences, Chemistry, vol. 56, no. 3, pp. 134-141, 2007.

[33] D. Ortelli, P. Edder, and C. Corvi, "Pesticide residues survey in citrus fruits," Food Additives and Contaminants, vol. 22, no. 5, pp. 423-428, 2005.

[34] S. Y. Foong, N. L. Ma, S. S. Lam et al., "A recent global review of hazardous chlorpyrifos pesticide in fruit and vegetables: prevalence, remediation and actions needed," Journal of Hazardous Materials, vol. 400, p. 123006, 2020.

[35] A. Gowda and H. L. Ramesh, "Analysis of pesticide residues in carrot retailed in vegetable markets in five districts of Karnataka, India," GSC Biological and Pharmaceutical Sciences, vol. 10, no. 3, pp. 027-038, 2020. 